\title{
Interruptions in Roman Comedy: Gender, Status, and Power in Interaction
}

\author{
Łukasz Berger \\ Adam Mickiewicz University in Poznań, \\ ul. Fredry 10, 61-701 Poznań, Poland; lberger@amu.edu.pl
}

For citation: Berger $Ł$. Interruptions in Roman Comedy: Gender, Status, and Power in Interaction. Philologia Classica 2021, 16 (1), 57-76. https://doi.org/10.21638/spbu20.2021.106

The article addresses the pragmatic and sociolinguistic constraints of interrupting in Roman comedy. It starts with a redefinition of the phenomenon informed by the methods of Conversation Analysis (CA): apart from syntactically incomplete utterances (as a result of interruptions by others), the analysis also includes the cases of interruptions reported by the characters. Furthermore, a distinction is made between intrusive (disaligning) interventions and other forms of competitive turn encroachments. The term 'interruptions', however, has been reserved only for the former, antagonistic type which serves to express disagreement and disinterest or to usurp the speaking turn. Using the revised criteria, the article proceeds to comment on quantitative data extracted from all the extant plays by Plautus and Terence. Accordingly, interruptions are viewed in relation to gender, age and status of the speakers, whereas some more detailed analysis concerns male and female citizens, prostitutes and servants. After comparing every character's share of talk with their proportional use of turn incursions (both collaborative and disruptive), it is argued that the violation of the turn-exchange system is significantly associated with some interlocutors and less so with others. The last section presents interrupting as a pragmatic means of exerting power in interaction while discussing the phenomenon also from a (sociolinguistic) cross-gender perspective.

Keywords: interruption, gender, social status, Plautus, Terence, Conversation Analysis, turn taking, male speech, female speech.

\section{Introduction}

The comedies by Plautus and Terence, with their vivid colloquial style and socially diversified characters, have served as a valuable source for pragmatic and sociolinguistic investigations of (early) Latin. ${ }^{1}$ This article aims at going one step further by examining not the stylistic features of the pre-classical Latin, but rather the organisation of the verbal

${ }^{1}$ See, for instance, the studies of female speech by Adams (1984) and Dutsch (2008), or Unceta's (2020) recent account of (over)polite strategies used by parasites and courtesans.

(C) St. Petersburg State University, 2021 
interaction represented in the text. I will offer an analysis of interruptions in fabula pallia$\mathrm{t} a$ in order to identify possible correlations between violations of conversational etiquette and the characters' gender, age, and social position. The topic has been occasionally addressed by other Latin scholars, but here the interruptions will be given a revised definition after applying the methods of Conversational Analysis (henceforth CA), which is an approach to study talk in ordinary circumstances. ${ }^{2}$ Thus, by a necessary simplification, the literary dialogues in Plautus and Terence will be treated almost as transcripts of naturally occurring conversations, organised in turns, namely spates of on-record talk produced and directed by one speaker to another. ${ }^{3}$

CA-informed studies show that, depending on the circumstances, not all the participants have the same speakership rights, while the orderliness of talk is correlated - on a higher level - with some organisational aspects of society. ${ }^{4}$ In this context, the readers of Roman comedy might think of the virgo, whose "visible speaking role would compromise the respectability of the young, unmarried, citizen woman character" (Witzke 2020, 337). Some types of interlocutors, in turn, not only have greater overall participation in dialogues, but in addition they can break into the speech given by others. The objective of this work is to indicate some sociolinguistic and situational constraints of interrupting in the reality of Roman comedy.

\section{Defining interruptions in Plautus and Terence}

In his account of interruptions in Roman comedy, Barrios-Lech $(2016,158)$ defines the phenomenon as "any encroachment on the speaker's turn, which leaves his or her talk incomplete". 5 This syntactical or turn-constructional approach can be illustrated by the example (1), in which Charmides starts to speak before his interlocutor produces a complete sentence. Although the utterance is unfinished, the intruder has - in his view recognised the intended action and has reacted accordingly.

(1) LES. Si quid tibi, pater, laboris -

CHAR. Nihil euenit, ne time. (Pl. Trin. 1181)

"LES. Father, if any distress - CHAR. I've had none, don't be afraid."

2 Within classical scholarship, see similar CA-informed investigations by Minchin (2007, 222-244), for Homer, and by Smith (2012), for a large corpus of ancient Greek narrative, including the Gospel. Evidence for (colloquial) Latin is gathered in Hofmann (1980, 174-178), while Müller (1997, 55-62) and Barrios-Lech $(2016,157-162,209-210)$ are the most extensive for the treatment of interruptions in Roman comedy. For a comprehensive introduction to CA, see Schegloff (2007) and-with an adaptation to dramatic discourse-Herman (1995).

${ }^{3}$ I follow here the definition of speaking turns by Edelsky $(1981,403)$, by which I exclude from the scope of study instances of non-official talking (e. g., theatrical asides), self-directed remarks, emotional outbursts, and backchannels (see Berger 2020a).

${ }^{4}$ From the perspective of CA, the relation between some sociologically relevant categories and the conversational practices or the organisation of talk is hardly straightforward, but using combined qualitative and quantitative methods reportedly may give satisfactory results (see further Heritage and Stivers 2013, 668-672).

5 Müller (1997, 55-56) prefers to analyse interruptions as cases of unauthorised and premature self-selections (Selbstwahl) of the other party, but - at the same time - all of his examples contain syntactically incomplete turns.

6 The Plautus text and its English translation follow the edition by de Melo (2011-2013). Terence's original and translation is quoted according to Barsby (2001). Given the main argument of the article, I modify some of the punctuation marks in order to indicate turn-space encroachments. 
While reading through the plays, however, one comes across overtly interruptive situations which do not meet the formal criteria of syntactical incompletion. In (2), the young citizen Phaedromus rebukes his slave for interrupting (obloquere) only after having realised that his contribution was an irrelevant (and playfully alliterative) comment. The distraction is further confirmed when the boy restarts his prior turn (ita ut occepi dicere), which proves that originally he had in mind a unit of talk longer than one sentence.

(2) PHAE. Lenonis hae sunt aedes.

PAL. Male istis euenat! /

PHAE. Qui?

PAL. Quia scelestam seruitutem seruiunt. /

PHAE. Obloquere.

PAL. Fiat maxume.

PHAE. Etiam taces? /

PAL. Nempe obloqui me iusseras.

PHAE. At nunc ueto. / <sed> ita uti occepi dicere: ei ancillula est. (Pl. Cur. 39-43)

"PHAE. This is the house of a pimp. PAL. Bad luck to it! PHAE. Why? PAL. Because it serves in scandalous slavery. PHAE. That's it, interrupt me. PAL. Yes, by all means. PHAE. Won't you be quiet now? PAL. But you told me to interrupt you. PHAE. But now I forbid you. But as I was about to say: he has a slave girl."

Therefore, for the interlocutors involved in a given speech event, an interruption seems to be not a mere feature of talk, but rather a kind of claim about what is going on in the conversation and - as such - it depends on their own evaluation of each other's behaviour (Bennet 1978, 562). To imply that the other party has interrupted means to complain about a possible offence of the turn-taking rules (Schegloff 2002, 301). This participants-oriented approach prevails in CA-informed accounts of interrupting, especially the ones interested in its normative aspects related to (im)politeness (e. g., Hutchby 2008). As for the ways the affected party might report the violation of their speaking rights, Bilmes (1997) identifies three major techniques:

i) the explicit claims of being interrupted (see (2));

ii) indirect verbal and non-verbal displays (e. g., by repetition, counter-interruptions);

iii) ignoring the content and the sequential implications of the interrupter's utterance.

The last mechanism can be found in the following excerpt where Lydus is bypassing the intervention by Mnesilochus, and then designing his following turn as a continuation of the prior.

(3) MNE. Quid factum est?

LYD. Meretricem indigne deperit -

MNE. Non tu taces? /

LYD. - atque acerrume aestuosam: apsorbet ubi quemque attigit. (Pl. Bac. 470-471)

"MNE. What's happened? LYD. He's shockingly in love with a harlot - MNE. Won't you be quiet? LYD. - and a wild whirlpool at that: she swallows anyone as soon as she touches him." 
Accordingly, one should distinguish claimable turn-taking violations (Lat. obloqui, interloqui, etc.) from non-hostile talking while someone else still holds the turn, such as in (1) above. As summarised by Schegloff (2002, 298-300), an unexpected intervention by the other party is likely, but not bound, to be taken as an interruption by the affected participant who evaluates it on the basis of its features and wider contextual constraints. Among many criteria used by the speakers, the scholar mentions the relationship of a possibly interrupting talk to the turn-in-progress: whether it is collaborative or antagonistic. In a similar vein, Barrios-Lech $(2016,157-159)$ argues that the interrupters in Latin comedy might try to exert dominance over the other party or show them support. ${ }^{7}$ Note that in the case of Phaedromus and his slave (2) the speech was evaluated as a violation quite late, only after the interrupted party had considered it unrelated and non-cooperative. Arguably, the analyst can use the same criteria for annotating cases of obloqui, as opposed to other forms of turn-space entries, in the comedy dialogues.

In general, the collaborative turn encroachments serve to help the current speaker with the on-going communicative action. Like in (1), they function as an affiliating device by saving the other party's speech-producing effort or by displaying a favourable attitude towards them. By contrast, the interruptions - in their proper disruptive sense - are salient turn entries aimed at taking control of the content or the process (2) of the conversation. Within this category, one finds intrusions which serve, such as in (3), to express disagreement and disapproval of the utterance or even of the other party as a speaker. Quite significantly, obloqui in Latin has a double meaning: 'to interrupt' and 'to contradict'.

Ultimately, I have decided to use the term 'interruptions' (with its negative connotations) to refer to the instances of intrusions which are reported as such (see (i-iii) above) or which - at least by their design - are conveying a disaligning stance (e. g., disagreement, disinterest). Accordingly, this definition combines two types of phenomena: of being interruptive (competitive, intrusive, etc.) and of being accused of interrupting, which may not always coincide (Hutchby, 1992; Bilmes, 1997; Berger, forth.). For the needs of the present argument, nonetheless, I assume that, whenever Plautus and Terence wanted to represent interrupters in their dialogues, they could resort to either of the stylistic and the dramaturgical resources: to the formal features of their interruptive talk or to the given character's ostensible reactions to the disruption. Admittedly, an interruption depicted on-stage is also an artistic means of expression and, as such, must be easily recognisable for the audience. On the other hand, the hostile turn-space intrusions coexist in the corpus with non-salient (aligning, collaborative, etc.) interventions which, when analysed together, can inform us about the general permeability of speaking turns in specific dyads of speakers.

7 The author distinguishes also a third, seemingly neutral, type of interruptions that result "from the speaker's excitement" (Barrios-Lech 2016, 158), which formally correspond to Müller's (1997) interjections (Einwürfe). Similarly, Goldberg (1990) classifies the interruptions into neutral ones (e. g., seeking for clarification) and non-neutral ones: either power- or rapport-oriented. On the other hand, a two-fold distinction of cooperative and disruptive interruptions (with different labels) can also be found in Tannen (1994), Murata (1994), and Li (2001) - with further subcategories. The terminological difficulties in designating non-hostile interruption-like behaviour is addressed in James and Clarke (1993: 237-238).

${ }^{8}$ For some examples outside comedy, see Sen. Thy. 1004; Gel. 1.26.6 ('protest, disagree'), or Cic. Clu. 63.5-6; Liv. 1.40.6; Sen. Con. 9.3 ('disturb, interrupt'). 


\section{Interruptions by character type in Roman comedy}

I proceed now to the distribution of any turn-space entries among different stock characters. Due to this paper's redefinition of interrupting and more nuanced criteria of their coding, this section will try to revisit Barrios-Lech's (2016: 160) general conclusion that 'the interruptions are distributed randomly throughout the plays of each author'. Accordingly, I have counted all the turns by given character types directed on-stage to another addressee. As shown in Figure $1^{9}$ (for Plautus) and Figure 2 (for Terence), I have compared their corresponding share in the overall number of dialogical turns with the proportional use of turn-space encroachments by speaker types.

Roman comedy, needless to say, is extremely ill-balanced in terms of representing talk by men and women, since most of the dialogue (and stage action) is done exclusively by male characters. Hence one should be cautious with any generalising observations, especially based merely on quantitative data. Having these issues in mind, we may initially assume that turn encroachments, of any type, are performed by every kind of character proportionally to the number of turns assigned to them in the plays; anybody who participates in a conversation at some point can (and will) speak out of turn. After comparing the statistical data, however, one notices that this phenomenon of the turn-exchange system is significantly associated with some interlocutors and less so with others. In relation to the level of participation in the corpus, most liberty is assigned by both authors to powerful citizens: old men and dowered wives. Conversely, their servants are very unlikely to encroach upon someone else's speaking turn. Among the low-status characters, speaking out of turn is characteristic of parasites (in Plautus) and tricky slaves (in Terence). More

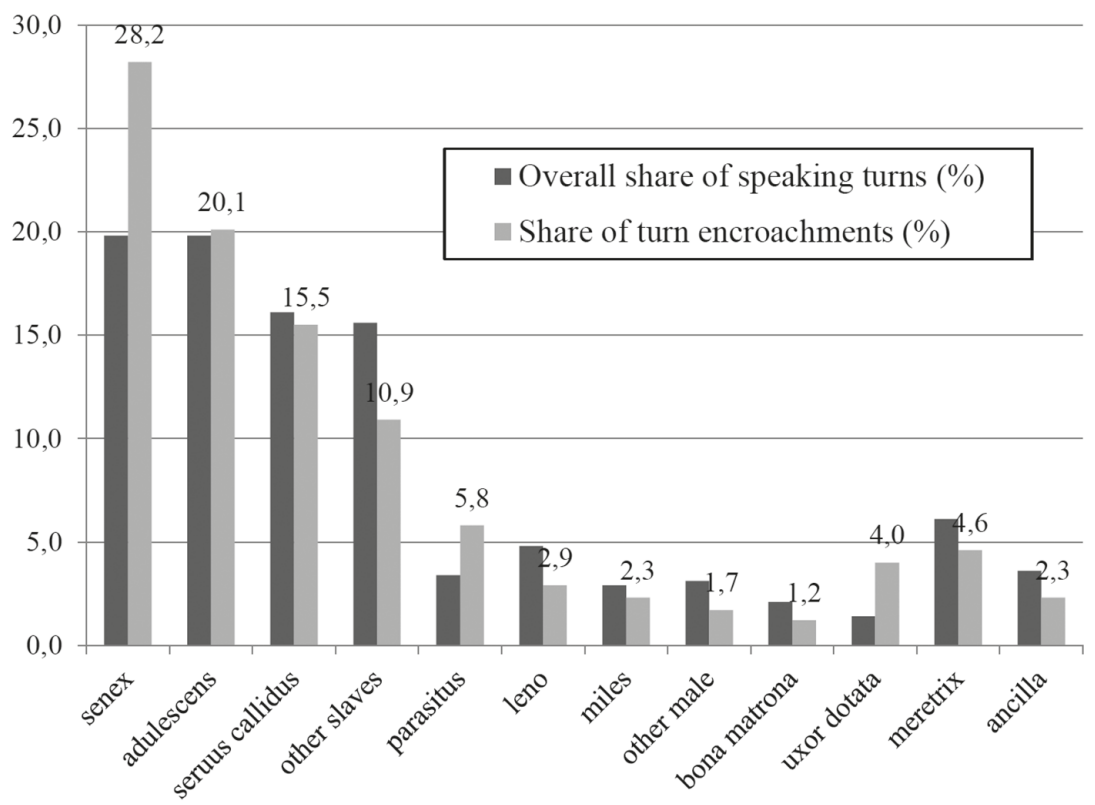

Fig. 1. Proportion between the share of speaking turns and of turn encroachments in Plautus (by character type)

9 All the figures are my own. 


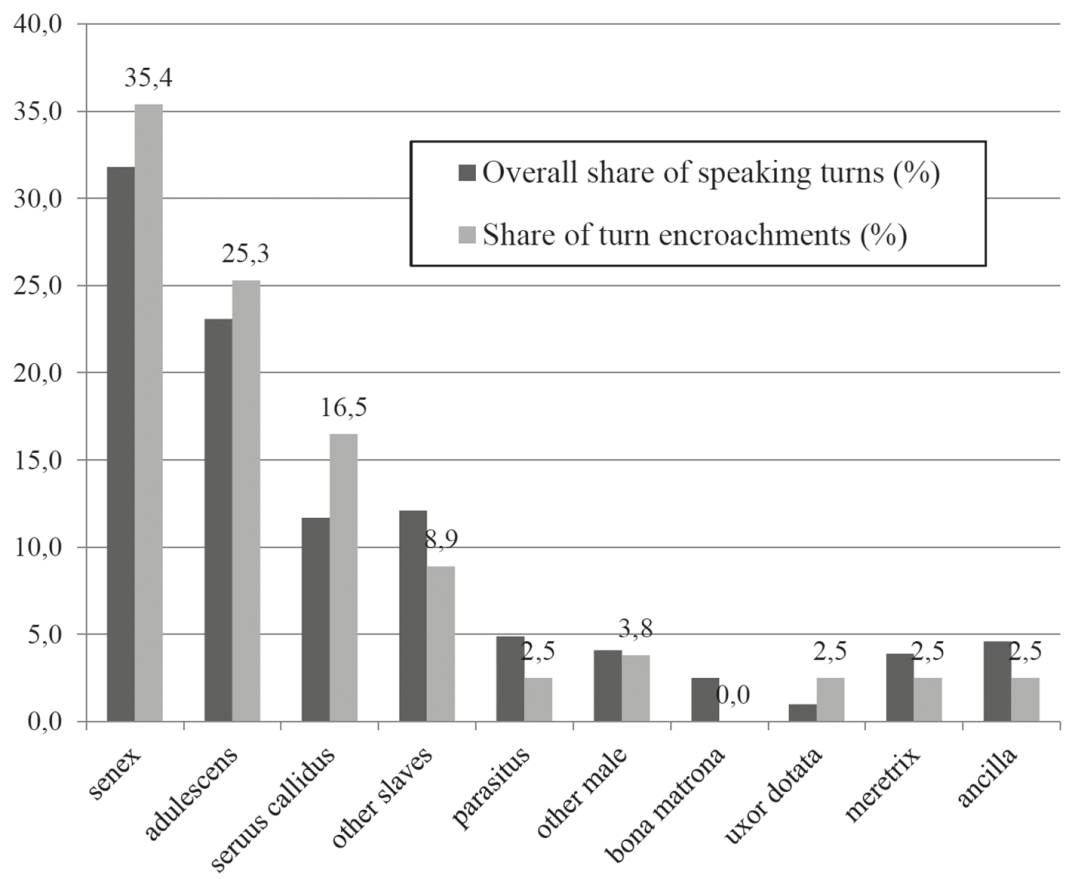

Fig. 2. Proportion between the share of speaking turns and of turn encroachments in Terence (by character type)

detailed data will be offered in the following sections, due to limitations of space, with special attention devoted to the members of citizen-class households and courtesans.

\section{Fathers and sons}

As previously indicated, male citizens in Roman comedy have the most liberty to access the speech of others. Figure 3 (below) compares the data in Plautus and Terence by providing the corresponding percentage of interruptions and non-intrusive interventions performed by free-born men proportionally to the overall numbers in each author. Accordingly, the younger generation in Terence seems to reproduce the speech patterns of their fathers: both groups interrupt more frequently than might be expected (see Figure 2), while being overwhelmingly competitive in turn taking. By comparison, half of the turn encroachments by male citizens in Plautus - both young and elderly - have rapport-oriented functions. In his plays, however, there is a clear generational gap, since the senes speak out of turn much more frequently than their sons, although they are given almost the exact same share of talk (see Figure 1).

Depending on the circumstances, the old men - unlike the younger citizens - can access the turn space of any other character (both male and female) with different intentions. This variety holds especially for Plautus, where their insertions range from the most collaborative to the most disruptive and imposing. Megaronides, talking to his sister, provides examples of non-competitive encroachments, which serve to convey the speaker's attentive involvement (quid est id, soror?) in the interaction and his aligning stance (ita di faxint!) towards the content of the message. 


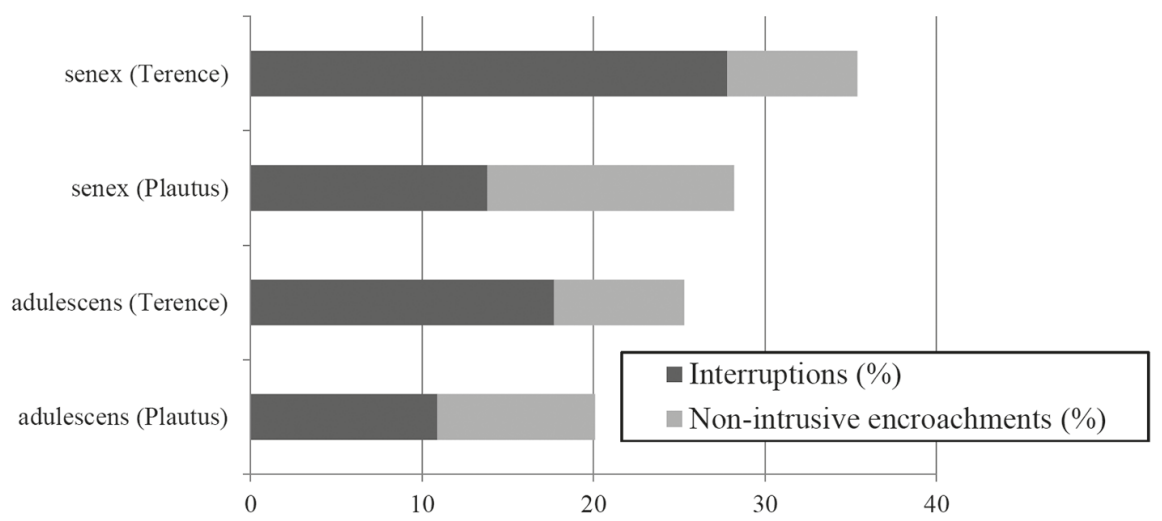

Fig. 3. Interruptions and non-intrusive turn encroachments by male citizens

(4) MEG. Soror, more tuo facis.

EVN. Facta uolo - ${ }^{10} /$

MEG. Quid est id, soror?

EVN. - quod tibi sempiternum / salutare sit: liberis procreandis -

MEG. Ita di faxint!

EVN. - uolo te uxorem / domum ducere. (Pl. Aul. 146-150)

"MEG. Dear sister, you are following your custom. EUN. I want it done - MEG. What's this, dear sister? EUN. - something that should be for your everlasting well-being. In order to beget children - MEG. May the gods grant it! MEG. - I want you to take home a wife."

Despite being prominent interrupters, the Plautine adult males very rarely speak in overlap with each other and if they do, these turn-space entries have exclusively a disruptive design. The old men in Terence, on the contrary, are prone to interrupt one another (more than a half of the interruptions are performed by senes in his corpus), but the frequency of this dyad may solely be related to the author's fondness for using antagonised pairs of the same stock characters in one play. In any case, the vast majority of the interruptions between old men in Roman comedy either convey a disagreement, or take a form of open struggles over the speakership in order to represent quarrels just like the one between the neighbours in (5). ${ }^{11}$

(5) ALC. Quin nihili facio.

LYS. Quin me perdis.

ALC. Quin bene est. / Quin etiam diu morabor, quin cupio tibi - /

LYS. Quin -

ALC. - aliquid aegre facere.

LYS. Quin faciam lubens. / numquam tibi hodie "quin" erit plus quam mihi. (Pl. Cas. 605-608)

10 As noted by Walker's $(2005,175)$ commentary, the line is problematic and ambiguous, since facta uolo might refer to the previous turn ('I agree') or project an upcoming proposal ('I want something to be done'). Following the scholar's suggestion, I opt for the latter interpretation-with a collaborative intervention by the other party-which explains better the use of quod in the following turn.

11 The few examples in Plautus consist of three instances of interrupting to express disagreement or protest (Aul. 560, Cas. 606-607, 607). By contrast, the disaligning stance in Mos. 806-809 has a politeness-related function. 
"ALC. But I don't care. LYS. But you're the ruin of me. ALC. But that's good. But I'll even delay her for a long time. But I wish - LYS. But - ALC. - to do you some harm. LYS. But I'll do the same to you, and with pleasure. You won't have more buts than me today."

It should be noted that Terence prefers a more nuanced turn-by-turn realisation of interpersonal tensions (e. g., animosities between brothers). ${ }^{12}$ However, the interruptions between his older-generation citizens are still salient due to being verbally recognised either by the affected party or by the intruder himself. Let the interruption marker mane ('hold on!') used by Micio in (6) be an example here.

(6) MIC. [...] haec si uoles / in animo uere cogitare, Demea, / et mihi et tibi et illis dempseris molestiam. /

DEM. Mitto rem: consuetudinem ipsorum -

MIC. Mane: / scio: istuc ibam. [...] (Ter. Ad. 817-821) ${ }^{13}$

"MIC. [...] If you think this through properly, Demea, you'll spare me and yourself and them a lot of trouble. DEM. Never mind about the money. It's the way they both live - MIC. Hold on! I know. I was coming to that [...]."

By comparison, young men are blatantly interrupting only another adulescens or low-status characters (especially their slave comrades ${ }^{14}$ ) whenever their interlocutors are about to deliver important news or they are asked to offer solutions to the current problems. Accordingly, these repetitive turn-space incursions contribute to an overall characterisation of the younger male generation as desperate, emotionally driven, and impatient. Still, the adulescens respects the turn space belonging to any elderly men with a higher authority or to women. The only exceptions are two youths from Terence's Eunuchus who interrupt the 'good' courtesan Thais. In (7), she is asking her jealous lover Phaedria to leave the town for two days.

(7) THA. Profecto non plus biduom aut -

PHAE. 'Aut' nil moror. /

THA. Non fiet: hoc modo sine te exorem.

PHAE. Scilicet / faciundumst quod uis.

THA. Merito te amo, bene facis. (Ter. Eu. 184-186) ${ }^{15}$

"THA. I assure you, not more than two days, or - PHAE. "Or"? I don't like the sound of that. THA. It won't happen. Just grant me this one thing. PHAE. Evidently I have to do what you want. THA. No wonder I love you. You're very kind."

Once the boy senses that the separation might last longer, he intervenes expressing his discontent and mistrust. This imposing interruption seems to mimic the behaviour

12 It is aligned with Hofmann's $(1980,176)$ view that the technique of interrupting is much more developed in Terence. See the appreciation of complex turn-taking techniques expressed throughout Müller (1997, 33-64).

${ }^{13}$ For other uses of mane signaling a turn-space intrusion in Terence, see Hau. 890 and Ad. 467. Many interruptions between old men start also with the emotionally charged interjections ohe! (Ad. 722) or ah! (Ad. 112-113, 127, 853, An. 872, Hau. 913). Less disruptive design, with no claims of violation, can be found in Ad. 728, Ph. 618 (effort-saving type) and An. 533, Hec. 771, Ad. 726-7 (turn usurpations).

14 The young citizen accesses the talk by a slave (Pl. Aul. 818, Bac. 470-1, 714-715, 731, 732, 745, Cur. 7, Poen. 167, Epid. 128, Mer. 161, 164, 180, 181, Mos. 364, Ps. 61; Ter. An. 683, Hau. 272, 317, 318, 690, 691, 978, 984, Ph. 198, 471) and a parasite (Pl. Cur. 356-357, St. 496, 629).

15 The other example is Chaerea's co-operative encroachment in Ter. Eu. 889. 
of elderly men when they are exerting power over defiant women, including their wives, daughters and courtesans. ${ }^{16}$ Phaedria's dominating tone, however, quickly fades away when he reluctantly admits that the lover has full control over him. By comparison, the Plautine young citizens - generally more emotional and passive - are always victims of the interruptions performed by courtesans (see (11) below). Hence one can argue that a more domineering turn-taking style by the Terentian young citizens goes hand in hand with their gradually developing adult masculinity. ${ }^{17}$ Significantly, Phaedria interrupts (twice) also his defeated rival, a braggart soldier, in a scene which does not take place in Plautus. ${ }^{18}$

Since the adulescens never interrupts older-generation citizens, the only examples of turn usurpations by Charinus talking to his father in Mercator (8) deserve our special attention. In this unique scene, the struggles between both men over speakership coincide with the fact that they are rivals pursuing the favours of the same girl.

(8) DEM. Viginti minis opinor posse me illam uendere. /

CHAR. At ego si uelim, iam dantur septem et uiginti minae. /

DEM. At ego -

CHAR. Quin ego, inquam -

DEM. Ah, nescis quid dicturus sum, tace. (Pl. Mer. 429-431)

"DEM. I think I can sell her for twenty minas. CHAR. But if I want to, I'll be given twenty-seven now. DEM. But I - CHAR. No, I, I say — DEM. Ah, you don't know what I'm going to say; be quiet."

Significantly, a whole series of Charinus' disrespectful intrusions are always reported verbally by the older interlocutor who disciplines him (Ah, nescis quid dicturus sum, tace). ${ }^{19}$ Therefore, in normal circumstances, it must have been unacceptable for a son to interrupt the paterfamilias or, for that matter, any elderly man. In Terence, a son is advised by a slave to confront his angry father in a 'tit for tat' (Ter. Ph. 212-213), but he eventually runs away scared and leaves the talking to others.

\section{Wives and prostitutes}

In the case of female characters, the qualitative analysis should be preferred to the quantitative data if one considers their humble representation in the corpus. Turn-space incursions by women in Plautus and Terence is sporadic (only 11.1 percent of all the cases in Roman comedy) and - with a significant exception of a domineering wife (uxor dota-

16 See turn-space encroachments by a senex, while talking to his daughter (Pl. St 91, 94), his wife (Cas. 248-249), his sister (Aul. 147, 148-149), a free-born ex-lover (Epid. 561) and courtesans (Mer. 503; Ter. Hec. 743-745). Menaechmus (Pl. Men. 609), the only younger-generation man interrupting his wife, serves as a bridging-case example in Plautus.

${ }_{17}$ Compare with James $(2013,183)$, who states that Terence-unlike Plautus (see Witzke 2020, 332333 - - shows his adulescentes on a spectrum of adult masculinity. However, the scholar has in mind 'sexual rights to bodies of others', not to their turn space.

18 See Ter. Eu. 1063, 1066. In the latter case, however, Donatus suggests that the soldier's turn might be an elliptical expression.

19 Overall, Charinus interrupts his interlocutor three times (Pl. Mer. 424, 431, 455) in one interaction, and all the violations are explicitly claimed by the father $($ Mer. 426, 231, 456). There are also two nonintrusive encroachments in Pl. As. 882-883 (a son to his father, who tries to share his girl) and Aul. 759-760 (a young citizen unjustly accused by an unrelated old man). 
ta) - it is roughly proportional to the small share of talk given to them on stage (see Fig. 1 and 2). The fact that the interruptions performed by women is not very significant for their characterisation is aligned with Adams' (1984) general assessment of female speech in fabula palliata as deferential, conciliatory and polite. Within the plays, however, women - including those of citizen status - are described mostly as garrulous (cf. Kruschwitz 2012, 223-225). Free-born Eunomia warns her brother about such female loquacity (Pl. Aul. 120-126), while herself making too many preambles, which forces her male interlocutor to cut in (see (4) above). Elsewhere, the comedy husbands interrupt their wives whenever their female partners get carried away with their nagging and tiresome talking. ${ }^{20}$ Hence, one of the good wishes directed to a slave bride (Pl. Cas. 821-822) is that her speech prevails over the one by her husband (tuaque uox superet). From this it follows that an ideal (married) woman should never have an upper hand in a conversation: she should be either silent or demonstrate extreme restraint in talking. ${ }^{21}$ Accordingly, the only clear depictions of blatant turn-taking violations by the respected Roman matronae belong to the dowered wife. ${ }^{22}$ Philippa's interruption of an elderly male citizen (Pl. Epid. 554-555) is a case in point, given that she is the only unmarried free-born woman in comedy.

In many aspects, the uxor dotata type, which has more authority in the household, is depicted as a female anti-model: bossy, repulsive and immoderate in talking. ${ }^{23}$ Within the analysed data, I can find eight cases of dowered wives interrupting their husbands, whereas all of these violations play a great role in their characterisation. Usually, the woman interrupts during confrontations with an unfaithful spouse, when she tries to take control over family affairs. Hence the interruptions by the uxor dotata contribute both to her dominating pattern of speech and to the humiliation of the paterfamilias. In (9), Dorippa has returned early from the country estate, just in time to find in the home a new maid who, as she suspects, is her husband's mistress.

(9) LYS. Vin dicam quoia est? illa - illa edepol - [...].

DOR. Haeres.

LYS. Haud uidi magis. /

DOR. Quin dicis?

LYS. Quin si liceat -

DOR. Dictum oportuit. /

LYS. Non possum, ita instas; urges quasi pro noxio. /

DOR. Scio, innoxiu's.

LYS. Audacter quam uis dicito. / [...]

20 Pl. Cas. 248-251, Men. 609; Ter. Hau. 879-882.

${ }^{21}$ E. g. Pl. Rud. 1114: tacitast melior mulier semper quam loquens, 'a woman is always better silent than speaking. For a general characterisation of 'good' wives and marriage ideals, see Williams (1958) and González-Vázquez (2012).

${ }^{22}$ All the turn-space entries by wives without a dowry are either problematic or concern low-status characters. In Pl. St. 335-338, Panegirys' intervention is qualified as interruptive by her interlocutor, a talkative slave who bypasses her ironic remark. Alcumena's interruption in Pl. Am. 520 is treated as an off-floor contribution and arguably falls at a prosodic break (achieved by a hiatus) after a suspended turn (Hofmann 1980, 175).

${ }_{23}$ Accordingly, the uxor dotata is often compared to a barking bitch (Pl. Cas. 320; Mil. 681). Braund (2005) discusses aspects of marriage and dowry in Roman drama. For a general characterisation of dowered wives, see Dutsch (2008: 81-85) and Barrios-Lech (2016: 44-45). See also Krauss (2004) who challenges the traditional distinction between the 'good' and the 'bad' wife with a more nuanced analysis. 
DOR. Nihil agis, / manufesto teneo in noxia.

LYS. Qua noxia? / istaquidem illa est.

DOR. Quae illa est?

LYS. Illa -

DOR. Quoia ea est? /

LYS. Iam — si nihil usus esset, iam non dicerem. (Pl. Mer. 722-731)

"LYS. You ask who she belongs to? DOR. I'll find out anyway. LYS. Do you want me to say who she belongs to? She - yes, she - [...]. DOR. You're stuck. LYS A likely story. DOR. Why don't you tell me? LYS. Well, if I were allowed to - DOR. You ought to have said it already. LYS. I can't, with you pushing me so much; you're pursuing me as if I were delinquent. DOR. I know you're guiltless. LYS. You can say that as boldly as you wish. [...] DOR. You're getting nowhere, I've caught you red-handed in a crime. LYS. What crime? She's that one. DOR. Which one? LYS. She - DOR. Who does she belong to? LYS. Now - if it weren't necessary I wouldn't tell you at present."

Taken off guard, the old man stumbles while trying to figure out some plausible explanation. Dorippa uses his hesitating speech twice as an opportunity for turn-space intrusions. Both of these encroachments are competitive and power related. Instead of having a floor-supporting function (cf. quid est id? in (4)), they express the interrupter's insistence and exasperation (see ita instas, 'you're pushing me so much'). Similar dynamics are repeated in a scene from Plautus' Casina (979-982), in which the triumphant Cleostrata repeatedly interrupts her husband when he cannot find any excuse for his misdeeds (Berger 2020b, 31-32). It might be significant, however, that in such scenes the paterfamilias is helpless and at a loss for words. ${ }^{24}$ Ultimately, the dowered wife is not represented as gaining control over the male turn space: her conversational dominance is possible only if the master of the household loses it by his own fault (cf. Fantham 2015, 102).

The telling example from Terence, the only representation of an uxor dotata interrupting a man other than her own spouse, shows that the female turn usurpations are in fact easy to suppress. Here (10) the domineering wife Nausistrata is complaining about the husband who squandered her dowry. Her brother-in-law barely starts to talk when the angry woman cuts in and changes the topic. At first the man is being cooperative and accepts this abrupt manoeuvre, while agreeing with her (certo scio) in what seems to represent simultaneous speech. Then he decides to reclaim the floor.

(10) NAV. [... nam ex is praediis talenta argenti bina / statim capiebat: uir uiro quid praestat!

DEM. bina quaeso? /

NAV. Ac rebus uilioribus multo tamen duo talenta.

DEM. Hui! /

NAV. Quid haec uidentur?

DEM. Scilicet -

NAV. Virum me natam uellem: / ego ostenderem -

DEM. Certo scio.

24 Besides Dorippa, Cleostrata and Nausistrata, the other interrupting uxor dotata is Artemona. In Pl. As. 921-926, her husband Demaenetus is less hesitant, but he emits two desperate cries, while Artemona is restlessly repeating surge, amator, i domum ('Get up, lover, go home'). The domineering woman interrupts him the minute he addresses her uxor. For husbands complaining about having to surrender to the authority of their dowered wives, see Pl. As. 78-79, 87; Cas. 409. 
NAV. - quo pacto -

DEM. Parce sodes, / ut possis cum illa, ne te adulescens mulier defetiget. /

NAV. Faciam ut iubes. [...] (Ter. Ph. 789-795)

"NAU. [...] He used to get in two talents of silver regularly from those estates. How one man differs from another! DEM. Two talents, did you say? NAU. Wow! DEM. What do you think about it? DEM. Evidently - NAU. I wish I'd been born a man. I'd show him - DEM. I'm quite sure you would. NAU. - how - DEM. Please spare yourself, so that you can deal with her. She's a young woman and she may tire you out. NAU. I'll take your advice. [...]"

Through a counter-interruption, Demipho takes control of the conversation and pacifies the domineering matrona. It might be significant that, in her attempt at using competitive style of turn taking, Nausistrata was deploring the fact that she had not been born a man. ${ }^{25}$ Demipho politely asks his interlocutor to save her discourse for the daughter-inlaw who is a more challenging opponent, whereby he seems to be hinting at a stereotypical female verbosity.

As for the courtesans, their turn-space entries are even more markedly intrusive than the one by domineering wives. On the other hand, I can find no major difference in this aspect of turn taking between an actual prostitute (meretrix) and her free-born apprentice (pseudomeretrix), which suggests that it is more related to the types of interaction available for both characters onstage than with their citizen origin. ${ }^{26}$ It should be noted, however, that all the interrupting courtesans are not enslaved and - by the usurpations of speakership - they enact their liberty to dismiss, contradict or correct their male clients. ${ }^{27}$ Selenium, a free-born girl raised to be a prostitute, serves as an illustrative example of this type of incursion into the male turn space. The girl is trying to free herself from an insistent lover by interrupting twice his apologies and attempt to finish the conversation. ${ }^{28}$

(11) ALC. Opsecro te -

SEL. Valeas.

ALC. - ut sinas -

SEL. Nil moror.

ALC. - expurigare me. /

SEL. Opressas.

ALC. Sine dicam. (Plaut. Cist. 453-4)

"ALC. I beg you — SEL. Goodbye. ALC. - to let me - SEL. I don't care. ALC. — apologise. SEL. You're being violent. ALC. Let me speak."

25 On the complexity in the depiction of Nausistrata as a dowered wife, see Barrios-Lech $(2016,160$ 162).

26 Similarly, Unceta $(2020,303-310)$ states that both female characters use the same strategies of manipulation with their clients. On the other hand, Barrios-Lech $(2016,151-153)$ argues that-in comparison to the meretrix - the speech by the pseudo-courtesan is markedly more polite.

27 See the power-related interruptions by Phronesium (Pl. Truc. 935-936) and Erotium (Men. 688), two instances of interrupting (only one intended) by Bacchis (Ter. Hec. 743-745), and three correcting or disaligning turn encroachments by the procuress Melaenis talking to her daughter's client (Pl. Cist. 497-498, 514-515, 515-517). One of Phronesium's lovers appreciates her agility in conducting a dynamic and witty conversation (Pl. Truc. 939: STRAT. Par pari respondet 'She's quick at repartee').

${ }^{28}$ In the case of a pseudomeretrix, the turn-space entries by courtesans might serve as a characterisation device particularly prominent if it precedes the moment of recognising the girl as a free-born citizen: see Adelphasium interrupting a stranger who turns out to be her father (Pl. Poen. 1216-1218). 
As duly remarked by Barrios-Lech $(2016,160)$, the interruptions by a courtesan are 'one linguistic indicator of her temporary ascendency over her hapless beloved. Once the power relation changes, however, the woman should yield to the male authoritative style of talking. One telling example is Lemniselenis, after she was purchased and freed by her beloved (slave) Toxilus. When the girl tries to oppose him, she is abruptly interrupted and reminded that she owes her patron obedience (cf. Witzke 2020, 343).

(12) LEM. At tamen non - tamen -

TOX. Caue ergo sis malo, et sequere me. / te mihi dicto audientem esse addecet, nam hercle absque me / foret et meo praesidio, hic faceret te prostibilem propediem. [...] (Pl. Per. 835-837).

"LEM. But still, I don't - still - TOX. Do watch out for trouble then and follow me. You ought to be obedient to me, because if it hadn't been for me and my protection, he'd have turned you into a prostitute without delay [...]"

Thus, it should be stressed that in all of the mixed-gender interactions discussed in this section the interruptions are not only a sign of one's dominant position, but they are also used by the playwrights to mark a shift in the dynamic of the relationship men have with women.

\section{Male and female slaves}

While analysing the speech of low-status characters in comedy, it seems useful to make a distinction between the seruus callidus and other, secondary, slaves. In both playwrights, the latter are very unlikely to take over someone else's turn..$^{29}$ The slaves' obedience to orderly turn-taking rules follows from the common idea shared by the slave-owners that a servant has to 'have his eyes, hands, and speech under control. ${ }^{30}$ There is only one clear case of an ill-disciplined slave interrupting his master's talk, but he is immediately rebuked by free-born characters, which only reinforces a normative vision about the conversational behaviour of the unfree subordinates. ${ }^{31}$

In fact, not even the tricky slaves - neither in Plautus nor in Terence - are seen to rudely interrupt their old master or any other senex. ${ }^{32}$ The only case of a trickster committing blatant violations of the turn-exchange system with an older-generation man is

${ }^{29}$ In Terence, most of the cases belong to Parmeno, a slave figure which combines obedience with the features of a tricky slave. He interrupts a courtesan three times (Ter. Eu. 107, 128, 463) and once-with a cooperative function-her maidservant $(E u$. 954). The rest are non-competitive insertions performed by Geta, while talking to another slave (Ph. 110) or a young citizen $(P h .198)$.

${ }^{30}$ Cf. Pl. Mil. 564-5, Per. 280-280a. On the preference for the slave's silence in comedy, see Barrios-Lech $(2016,229)$ with further examples. Stewart (2012) offers a discussion on the slave's strategic use of silence.

${ }^{31}$ On the other hand, Plautus is very fond of representing secondary and ill-disciplined male servants self-selecting as the next speaker in multiparty conversations: see, for instance, multiple disruptions of the conversational floor by Trachalio (Pl. Rud. 110-147) and Gripus (1054-1120).

32 Overall, there are eight cases of a rebellious slave encroaching upon the turn-space of a senex: four in Terence (Ad. 419-420, 768-769, 770, Hau. 780) and four in Plautus, performed exclusively by Tranio (Most. 517-518, 620, 722, 1079). Except for the scene with the drunken Syrus (Ter. Ad. 768-772), if they have a competitive design (Ad. 419-420; Pl. Most. 517-518, 722) - by other contextual constraints - they do not seem to be evaluated as impolite nor do they trigger any claim of violation. 
when he (temporarily) loses self-control. In (13), Syrus exits his house partially drunk and bumps into his owner's brother.

(13) SY. [...] quid fit? quid tu es tristis?

DE. Oh, scelus - I

SY. Ohe iam: tu uerba fundes hic, Sapientia? /

DE. Tu si meus esses -

SY. - dis quidem esses, Demea, / ac tuam rem constabilisses.

DE. - exemplo omnibus / curarem ut esses. (Ter. Ad. 768-772)

"SYR. [...] How are things? Why are you so gloomy? DEM. Oh, you villain - SYR. Hold on now! Are you going to bandy words here, Mr. Wisdom? DEM. If you were my slave SYR. You'd be a rich man, Demea; you'd have secured your fortune. DEM. I'd make you an example for everyone."

In reaction to the verbal abuse by his interlocutor, the Terentian comic hero interrupts twice: first with a strong interruption marker (ohe iam), and then he resorts to an anticipatory completion of the turn-in-progress which is aimed at disarming the speaker's threatening tone.

On the other hand, such competitive turn-space encroachments performed by the Terentian tricky slaves seem to form an important part of their linguistic characterisation (see Figure 2). Quite surprisingly, the serui callidi in Plautus - much more developed and famously in control of the onstage verbal interactions - break into the speech by others proportionally to their overall share of talking (see Figure 1). If they gain dominance in the conversation, it is never, on the micro-scale, by rudely intruding upon their opponents' turn space. However, most of their encroachments on other occasions and with different interlocutors has, indeed, a strong competitive motivation (see Figure 4).

In general, if slaves - of any kind - are represented as freely intruding upon someone else's talk, it is either of another low-born character or their younger master, with whom they tend to have special liberties. Accordingly, the male servant and the adulescens talking in overlaps - sometimes many times in one conversation - is the most common scene-type with turn-space entries. This context constitutes more than half of all the interruptive behaviour performed by both characters. It is worth noting, however, that the adulescens tends to be less competitive in this configuration (e. g., by asking for clarification

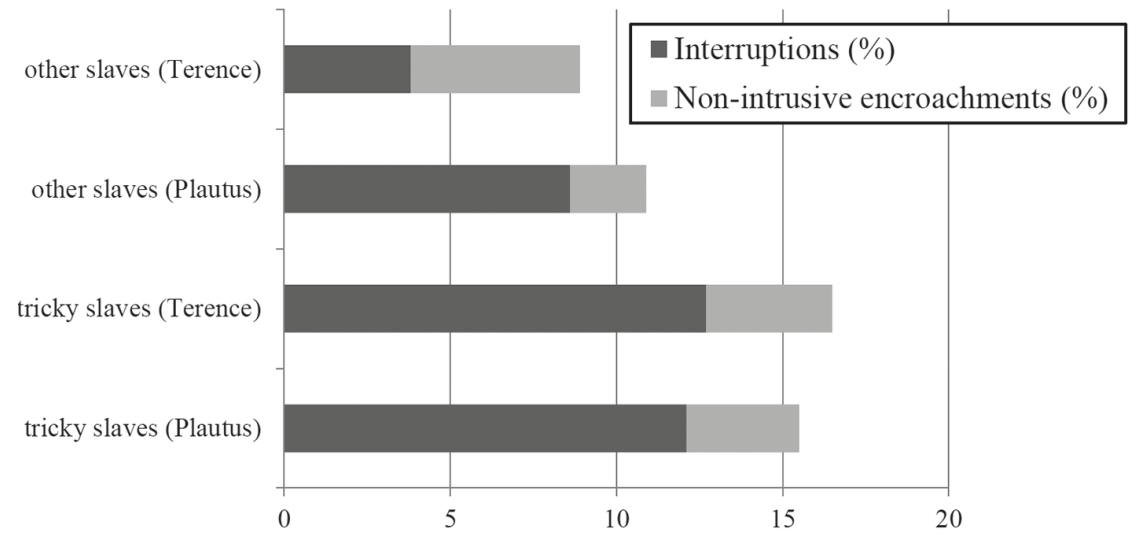

Fig. 4. Interruptions and non-intrusive turn encroachments by male slaves 
without seeking to take the floor), whereas slaves would more blatantly interrupt their hapless and helpless masters, on occasions, conveying a strong disaligning stance. This, however, does not mean that the servants come across as intrusive or impolite, given that there rarely are any explicit claims of violations. Plautus offers one of the extreme cases in (14), where the adulescens insistently continues his high-spirit talk despite multiple interruptions by the tricky slave Milphio who tries to bring the whole conversation to a halt.

(14) AGO. Egone, egone, si istuc lepide effexis -

MIL. I modo. /

AGO. - ut non ego te hodie -

MIL. Abi modo.

AGO. - emittam manu - I

MIL. I modo.

AGO. - non hercle meream -

MIL. Oh!

AGO. Vah -

MIL. Abi modo. (Pl. Poen. 428-430)

"AGO. If you sort this out nicely, I, I — MIL. Just go! AGO. — if today I don't — MIL. Just go! AGO. — set you free - MIL. Just go! AGO. — I really wouldn’t deserve - MIL. Oh! AGO. Bah - MIL. Just go!"

One has to bear in mind here that, in a typical comedy plot, the relations between the young boy and the cunning slave are very familiar and confidential. The clever servant helps the adulescens with his love affair by providing money and concealing the juvenile's misdeeds from the old father. Hence the desperate boy becomes the slave's dependent accomplice. This theatrical role reversal goes even further: on some occasions the clever servant is implied to be a symbolic extension of his young master's persona. ${ }^{33} \mathrm{~A}$ higher permeability of the turn space during a dynamic conversation seems to be one of the consequences of this representation.

Finally, I turn to the maidservants, who notably restrain from intruding upon other's talk. This is especially true for Terence, whose ancillae have the biggest share of turns among all his female characters but, significantly, they speak out of turn only twice. In addition, the only examples of fully-fledged interruptions are performed by maidservants of courtesans. ${ }^{34}$ There are two cases when ancilla, who serves in a household of a citizen, intervenes before the other party finishes. One is Mysis agreeing to her young master's instructions before she rushes off the stage (Ter. An. 300). In the other, Pardalisca, more loyal to the mistress of the house, tries to trick Lysidamus, her wayward husband, into believing that his life is in danger.

(15) LYS. Heus, Pardalisca! /

PAR. Quid est?

LYS. Est -

33 See McCarthy (2000: 20-21), Stewart (2012: 50-55) for a more extensive discussion about Cato's vision of the slave-master relation, and Barrios-Lech (2016: 229-231) quoting relevant passages from the comedy.

34 See Astaphium (Pl. Truc. 753) and Pythias (Ter. Eu. 1019), who, according to Barrios-Lech (2016, 160 ) is showing here her dominance over the male trickster of the play (see further Martin 1995). Other collaborative turn-space entries by female servants of a courtesan are found in Pl. Mil. 1026 and Truc. 756. 
PAR. Quid?

LYS. Est quod uolo exquirere ex te. /

PAR. Moram offers mihi. /

LYS. At tu mihi offers maerorem. sed etiamne habet nunc Casina gladium? /

PAR. Habet, sed duos. (Pl. Cas. 688-692)

"LYS. Hey there, Pardalisca! PAR. What is it? LYS. There is - PAR. What? LYS. There is something I want to ask you. PAR. You're delaying me. LYS. And you are saddening me. But does Casina still have a sword? PAR. She does; two, actually."

The maidservant's turn-space encroachment has no overt competitive design, but she sounds exasperated while complaining about the frightened man's beating about the bush (moram offers mihi). Interestingly enough, like in other scenes with a senex amtor (see (9) above), the female turn-space incursion seems to be triggered by the male hesitant production of utterance.

\section{Discussion: Interruptions, gender, and turn-taking style}

Among the most frequent and dramaturgically significant depictions of interrupting (in its proper disruptive sense), I have found the following contexts:

i) quarrels between male peers, e. g., (5), (6);

ii) mutual turn-space entries between an adulescens and the family slaves, e. g., (2), (14);

iii) master of the house interrupting the members of his family (son, daughter, wife, servants), e. g., (8);

iv) domineering wives interrogating their husbands, e. g., (9);

v) courtesans interrupting their clients, e. g., (11).

The elements that dominate in the above situations are conflictual talk or powerstruggles and turn-taking violations by males. Accordingly, it can be argued that interruptions are either a restricted sociolinguistic feature of talk or a general conversational practice. The fact that powerful women, like bossy wives (iv) and independent courtesans (v), are also prominent interrupters supports rather the latter explanation. Thus, turn-space intrusions are deployed by speakers with a superior - commanding and controlling position in the interaction regardless of their social standing. Interruptive talk, hence, becomes a pragmatic (and dramaturgical) mechanism of exerting power or taking over the communicative situation.

In all-male interactions, nonetheless, speaking out of turn has many more functions and it is not always related with being in charge or stressing the imbalance of power. According to Barrios-Lech $(2016,210)$, male friends are prone to access other's talk even outside a typical conflictual context, because they desire "to best the latter in witty banter or because he believes he knows better". By comparison, there is only one proper depiction of female-to-female turn incursion. All other cases of women speaking out of turn are when they are interacting with a man, and these encroachments are exclusively disruptive and antagonistic. Only maidservants are using (albeit very rarely) supportive turn-space entries with male interlocutors. The peculiar asymmetry in representing interrupting 
dyads makes one think of a much-debated cross-gender perspective in the scholarship on modern-day interruptions. ${ }^{35}$

One can explain this visible regularity in the comedy data with deficiencies of the corpus and the limited set of interaction types available to each gender. I have counted all the dialogues with (at least) two female or two male interlocutors and the proportions are approximately 1:5 (see Table 1). This means, indeed, that men have five times more opportunities than women to interrupt their own gender, but this still does not sufficiently explain the (almost) absolute absence of female characters speaking out of turn with each other.

Table 1. Gender of the interlocutors and the overall number of turn-space encroachments.

\begin{tabular}{|l|c|l|}
\hline \multicolumn{1}{|c|}{ type of interaction } & $\begin{array}{c}\text { number of interactions } \\
(\mathbf{1 0 0} \mathbf{)})\end{array}$ & \multicolumn{1}{|c|}{ turn-space encroachments } \\
\hline $\begin{array}{l}\text { at least two female speakers } \\
\text { (all-female dialogues) }\end{array}$ & $\begin{array}{c}69 \\
(28)\end{array}$ & $\begin{array}{l}\text { female-to-female: } 1(1.4 \%) \\
(3.6 \%)\end{array}$ \\
\hline $\begin{array}{l}\text { at least two male speakers } \\
\text { (all-male dialogues) }\end{array}$ & 340 & $\begin{array}{l}\text { male-to-male: } 191(56.2 \%) \\
(70.7 \%)\end{array}$ \\
\hline $\begin{array}{l}\text { mix-gender dialogues } \\
\text { (at least one male and one female speaker) }\end{array}$ & $(270)$ & $\begin{array}{l}\text { male-to-female: } 33(19.1 \%) \\
\text { female-to-male: } 28(16.2 \%)\end{array}$ \\
\hline total & 173 & 253 \\
\hline
\end{tabular}

Arguably, then, the comedy playwrights reproduce a somewhat biased vision of talk between female characters, with much less permeability of speaking turns. Dutsch (2008, 56-57) convincingly states that the gendered speech by women emphasises connectivity, conciliation, and closeness with the interlocutor. Even when women engage in some minor arguments, like the citizen sisters in Stichus (see Feltovich 2015b, 129-134), they are careful not to rudely interrupt one another. ${ }^{36}$ The only example of female-to-female turn encroachment seems to only confirm this rule. The case belongs to a short yet agitated misunderstanding between free-born wives (16), where Cleostrata, the bossy type, self-selects impatiently in the midst of her interlocutor's talk.

(16) MYR. Tace sis, stulta, et mi ausculta. noli sis tu illi aduorsari, / sine amet, sine quod lubet id faciat, quando tibi nil domi delicuom est. /

CLEO. Satin sana es? nam tuquidem aduorsus tuam istaec rem loquere.

MYR. Insipiens, / semper tu huic uerbo uitato abs tuo uiro -

CLEO. Quoi uerbo?

MYR. "i foras, mulier."

35 For gendered interruptions in English-speaking communities, for instance, see the critical overview in James and Clarke (1993), who stress the complexity of the issue and the inconclusive character of the available results.

${ }^{36}$ For Barrios-Lech $(2016,210)$, the only case of women interrupting each other is Pl. St. 29-31 where the matrona is intervening with a collaborative ita ut memoras ('Precisely as you say'). Nonetheless, it falls into a turn's possible completion point, so, according to my criteria, it should be qualified as a backchannel contribution (see further Berger 2020a). 
"MYR. Do be quiet, silly, and listen to me. Just don't oppose him, let him love, let him do what he likes, since you don't lack anything at home. CLEO. Are you in your right mind? You're speaking against your won cause. MYR. Stupid, always avoid this word from your husband - CLEO. Which word? MYR. "Go away, woman."”

It seems significant that out of all the talk between women, this clarification-seeking type (quoi uerbo?) is found only here, given that the circumstances are also special. The exchange takes place shortly after Cleostrata reminds her friend Myrrhina that they are alone and can speak freely (Pl. Cas. 196-198). James $(2015,110)$ understands these words as 'a striking sign of women's awareness that their speech is circumscribed'. The scholar notes that what comes next, unlike the beginning of their dialogue, is not marked by politeness nor typically female language but rather contains unmitigated expressions and terms of abuse (stulta, insipiens). On the conversational level, the turn-space encroachment appears next to marked floor-managing devices (tace, mi ausculta), which are associated elsewhere with a domineering 'male' turn-taking style. ${ }^{37}$ According to James (2015, 110 ), in the passage Plautus reproduces talk by women when, in the absence of men, they do not feel the need to perform their femininity.

\section{Conclusions}

In this article, I have applied a more nuanced criteria in examining the action of speaking out of turn by the characters of Roman comedy. The (proper) interrupting has been defined as turn-space intrusions which are instruments of competing over speakership or which serve to express a disaligning stance towards the interrupted talk. As such they have been distinguished from other, collaborative and non-salient, types of turn encroachments.

From the quantitative and qualitative analysis presented here, it follows that turnspace entries - either disruptive or collaborative - are prominent in the speech pattern of older-generation male citizens who enact their role of the paterfamilias. Other members of the household (wives, sons, servants) generally have less liberty to access the turnspace of their interlocutors, especially those with a higher authority. ${ }^{38}$

Furthermore, the interruptions appear typically as a power-related pragmatic device in agitated and conflictual talk. As such, however, it is not available equally to all characters and it is not employed in all types of dyads of speakers. I suggest that there is some gender-related bias in reproducing interruptive behaviour onstage. Admittedly, female interruptions are presented differently than the ones performed by men. Women are never depicted as interrupting each other, although in some specific situations, circumscribed as private, they are seen to use less mitigated and aggressive language similar to the one employed by men. The female characters resort to power-related interruptions only when

37 Cf. Müller (1997, 50-55). For the paterfamilias acting as floor manager (with special focus on Plautus' Casina), see recently Berger (2020b). This direct language of the passage had led scholars to suggest that these lines were attributed to a man in the Greek original, especially given Myrrhina's seemingly misogynistic ideas (see Feltovich 2015a, 247-248).

38 For arguments in favour of the naturalistic depiction of Roman family life in Terence, see Starks (2013, 141-143) and Packman (2013), with a comparison to Plautus. The discussion of the role and position of women in the household, as represented on-stage, is discussed by Fantham (2015). 
talking with male interlocutors, being courtesans generally more disruptive than dowered wives.

Even considering the overrepresentation of all-male dialogues, I suggest that men in comedy have more liberty in using - with some due restrictions related to their social position - a much wider range of turn-space encroachments. Accordingly, whereas interrupting appears as a conversational practice inherent to conflictual talk and possible in most of the dyads, one can still trace some biased set of speech patterns that correspond with Plautus and Terence's representations of gender and social class.

\section{References}

Adams J. N. Female speech in Latin comedy. Antichthon 1984, 18, 43-77.

Barrios-Lech P. Linguistic Interaction in Roman Comedy. Cambridge, Cambridge University Press, 2016.

Barsby J. (ed.) Terence. Comedies. Vol. 1-2. Cambridge MA, HUP, 2001.

Bennet A. Interruptions and the interpretation of conversation, in: D. Perlmutter et al. (eds). Proceedings of the 4th Annual Meeting of the Berkeley Linguistics Society. Berkeley, University of California, 1978, $557-75$.

Berger Ł. Forms of talk in Roman Comedy. Reading Plautus and Terence with Goffman and Conversation Analysts. Dionysus ex machina 2020a, 11, 137-167.

Berger Ł. Turn taking and power relations in Plautus' Casina. Graeco-Latina Brunensia 2020b, 25 (1), 19-35.

Berger Ł. Im/Politeness of Interruptions in Roman Comedy, in: L. Unceta and Ł. Berger (eds). Politeness in Greek and Latin. Cambridge University Press (forthcoming).

Bilmes J. Being interrupted. Language in Society 1997, 26 (4), 507-31.

Braund S. M. Marriage, adultery, and divorce in Roman comic drama, in: W. S. Smith (ed.) Satiric Advice on Women and Marriage: From Plautus to Chaucer. University of Michigan Press 2005, 39-70.

James D., Clarke S. Women, men, and interruptions: A critical review, in: D. Tannen (ed.) Gender and Conversational Interaction. Oxford - New York, Oxford University Press, 1993, 231-280.

De Melo W. (ed.). Plautus. Comedies. Vol. 1-5. Cambridge, MA, HUP, 2011-2013.

Dutsch D. M. Feminine Discourse in Roman Comedy: On Echoes and Voices. Oxford, Oxford University Press, 2008.

Edelsky C. Who's got the floor? Language in society 1981, 10 (3), 383-421.

Fantham E. Women in control, in: D. Dutsch, S. L. James, D. Konstan (ed.) Women in Roman Republican Drama. Madison, WI, University of Wisconsin Press, 2015, 91-107.

Feltovich A. In Defense of Myrrhina: Friendship between Women in Plautus's Casina. Helios 2015(a), 42 (2), 245-266.

Feltovich A. The Many Shapes of Sisterhood in Roman Comedy, in: D. Dutsch, S. L. James, D. Konstan (ed.) Women in Roman Republican Drama. Madison, WI, University of Wisconsin Press, 2015(b), 128-154.

Goldberg J. A. Interrupting the discourse on interruptions: An analysis in terms of relationally neutral, power-and rapport-oriented acts. Journal of Pragmatics 1990, 14 (6), 883-903.

González Vázquez C. La matrona plautina desde la 'realidad' teatral, in: F. De Martino, C. Morenilla (ed.) Teatro y sociedad en la antigüedad clásica. El logos femenino en el teatro. Bari, Levante Editori, 2012, $115-150$.

Heritage J., Stivers T. Conversation Analysis and Sociology. The handbook of conversation analysis, in: J. Sidnell and T. Stivers (eds). The Handbook of Conversation Analysis. Malden - Oxford, Wiley-Blackwell, 2013, 659-673.

Herman V. Dramatic Discourse: Dialogue as Interaction in Plays. London - New York, Routledge, 1995.

Hofmann J. B. La lingua d'uso latina (transl. L. Ricottilli). Bologna, Pàtron, 1980.

Hutchby I. Confrontation talk: Aspects of 'interruption' in argument sequences on talk radio. Text-Interdisciplinary Journal for the Study of Discourse 1992, 12 (3), 343-372.

Hutchby I. Participants' orientations to interruptions, rudeness and other impolite acts in talk-in-interaction. Journal of Politeness Research 2008, 4, 221-241.

James S. L. Gender and sexuality in Terence, in: A. Augoustakis, A. Traill (ed.) A Companion to Terence. Malden, MA, Wiley-Blackwell 2013, 175-94. 
James S. L. Mater, oratio, filia: Listening to mothers in Roman comedy, in: D. Dutsch, S. L. James and D. Konstan (ed.) Women in Roman Republican Drama. Madison, WI, University of Wisconsin Press, 2015, $108-127$.

Kruschwitz P. Language, sex, and (lack of) power: Reassessing the linguistic discourse about female speech in Latin sources. Athenaeum 2012, 100, 197-229.

Li H.Z. Cooperative and intrusive interruptions in inter-and intracultural dyadic discourse. Journal of Language and Social Psychology 2001, 20 (3), 259-84.

Lycan W. G. Conversation, politeness, and interruption. Paper in Linguistics 1977, 10 (1-2), 23-53.

Martin R. H. A Not-so-Minor Character in Terence's Eunuchus. Classical Philology 1995, 90(2), 139-151.

McCarthy K. Slaves, Masters, and the Art of Authority in Plautine Comedy. Princeton: Princeton University Press, 2000.

Minchin E. Homeric Voices: Discourse, Memory, Gender. Oxford, Oxford University Press, 2007.

Müller R. Sprechen und Sprache. Dialoglinguistische Studien zu Terenz. Heidelberg, Universitätsverlag Winter, 1997.

Murata K. Intrusive or co-operative? A cross-cultural study of interruption. Journal of Pragmatics 1994, 21 (4), 385-400.

Packman Z. M. Family and household in the comedies of Terence, in: A. Augoustakis, A. Traill (eds). A Companion to Terence. Malden, MA: Wiley-Blackwell, 2013, 195-210.

Schegloff E. A. Accounts of conduct in interaction: Interruption, overlap, and turn-taking, in: J.H. Turner (ed.) Handbook of Sociological Theory. New York, Springer, 2002, 287-321.

Schegloff E. A. Sequence Organization in Interaction. Cambridge. Cambridge University Press, 2007.

Smith D. L. The Rhetoric of Interruption: Speech-Making, Turn-Taking, and Rule-Breaking in Luke-Acts and Ancient Greek Narrative. Berlin - Boston, De Gruyter, 2012.

Starks Jr J.H. Opera in bello, in otio, in negotio: Terence and Rome in the 160s BCE, in: A. Augoustakis, A. Traill (eds). A Companion to Terence. Malden, MA: Wiley-Blackwell, 2013, 132-55.

Stewart R. Plautus and Roman Slavery. Malden - Oxford, Wiley-Blackwell, 2012.

Tannen D. Gender and Discourse. Oxford - New York, Oxford University Press, 1994.

Unceta Gómez L. The Politics of Manipulation: Politeness and Insincerity in the Language of Parasites and Courtesans in Plautus' Comedies, in: G. Martin et al. (ed.) Pragmatic Approaches to Drama. Studies in Communication on the Ancient Stage. Leiden-Boston, Brill, 2020, 291-316.

Walker J. A commentary on Plautus' 'Aulularia'. PhD dissertation, the University of St Andrews, 2005. Available at: http://hdl.handle.net/10023/14536 (17.04.2021).

Williams G. Some aspects of Roman marriage ceremonies and ideals. The Journal of Roman Studies $1958,48(1 / 2), 16-29$.

Witzke S. S. Gender and Sexuality in Plautus, in: D. Dutsch and G. F. Franko (eds). A Companion to Plautus. Wiley-Blackwell 2020, 331-346.

Received: December 15, 2020

Accepted: April 19, 2020 